\title{
Kaupallinen koulutus yhdentyvässä Euroopassa
}

SIECin (International Society for Business Education) 60. konferenssi järjestettiin 31.7.-6.8.1988 Salzburgissa, Itävallassa. Konferenssiin osallistui lähes 400 elinkeinoelämän, hallinnon, kaupallisten oppilaitosten ja yliopistojen edustajaa 16 maasta.

Konferenssin ohjelmaan sisältyi

— Itävallan koulutusjärjestelmän esittely, erityisesti kaupallinen koulutus,

- opettajakoulutus kaupalliselle alalle,

- opettajan asema tulevaisuudessa,

- opetusmenetelmistä mm. tietokoneavusteinen opetus,

- koulutuksen ja elinkeinoelämän yhteydet sekä

- opintokäyntejä koulutusorganisaatioihin (mm. aikuiskoulutuskeskus) ja yrityksiin.
Seuraavassa joitakin poımıntoja konferenssissa pidetyistä alustuksista ja keskusteluista, lähinnä konferenssin isäntänä toimineen Itävallan näkökulmasta.

\section{Kaupallinen koulutus Itävallassa}

Kaupallisella koulutuksella on Itävallassa pitkät perinteet. Tänä päivänä tärkeimmät kaupallista koulutusta antavat koulumuodot ovat 5-vuotinen Handelsakademie, joka päättyy ylioppilastutkintoon ja jonka suorittaneista suurin osa jatkaa yliopistossa tai korkeakoulussa ei välttämättä kauppakorkeakoulussa - ja 3-vuotinen Handelsschule. Näistä molemmista koulutyypeistä on olemassa ammatissa toimivia varten iltakoulut, jotka ovat kestoltaan vuoden lyhyemmät kuin vastaavat päiväkoulut. Näiden lisäksi kaupallista koulutusta antavat kaupalliset ammattikoulut, joissa koulutus tapahtuu oppisopimuspohjalta eli oppilaat ovat koulussa esim. vain yhtenä päivänä viikossa ja muun ajan oppivat ammattia käytännössä jossakin yrityksessä. Kaikkiin näihin kouluihin pääsyvaatimuksena on 8 luokkaa oppivelvollisuuskoulua. Koska oppivelvollisuus on 9 vuotta, niin ensimmäinen vuosi ammatillista koulutusta kuuluu vielä oppivelvollisuuden piiriin. Tavallisessa lukiossa ylioppilastutkinnon suorittaneita varten on olemassa Kollegkouluja, joissa kaupallisen tutkinnon voi suorittaa $11 / 2$ vuodessa.

Yleissivistävien aineiden osuus kaikista pakollisista aineista on hiukan yli puolet. Siihen määrään sisältyvät myös kielet (äidinkieli ja kaksi vierasta kieltä), joiden osuus on $30 \%$ kaikista aineista. Yleissivistävien aineiden suurta määrää perustellaan sillä, että ammatillisesta koulutuksesta saadaan optimaalinen tulos, kun siihen liittyy vankka yleissivistys. Tästä syystä kaupallisissa oppilaitoksissa opiskellaan $\mathrm{mm}$. historiaa, biologiaa, kemiaa ja fysiikkaa. Myös uskonto ja terveyskasvatus sekä pikakirjoitus ovat pakollisia aineita. Lisäaineina tarjotaan $\mathrm{mm}$. latinaa, filosofiaa, kotitaloutta, musiikkia ja urheilua.

Itävallassa on joissakin aineissa (mm. kauppamatematiikka ja kirjanpito) käytössä tasoryhmistys, joka toteutetaan lukuvuoden ensimmäisen viikon aikana. Ryhmäjakoa tarkistetaan useamman kerran vuoden aikana, jolloin siirrot ryhmästä toiseen ovat mahdollisia.

Kaupallisen koulutuksen kehittämistavoitteissa korostettiin erityisesti kolmea osa-aluetta. Ensinnäkin mainittiin tarve kehittää oppilaitten kommunikointi- ja yhteistyökykyä. Toiseksi arvioitiin, että vieraiden kielten opetuksen merkitys tulee kansainvälisen yhteistyön lisääntymisen myötä kasvamaan. Kolmas tavoite on tietojenkäsittelyn opetuksen integroiminen eri oppiaineisiin, jolloin tietojenkäsittelyn merkitys itsenäisenä oppiaineena vähenee.

Kaupallisten aineitten opettajaksi aikovan on syytä suorittaa ylioppilastutkinto Handelsakademiessa. Sen jälkeen hänen on hankittava parin vuoden työkokemus liikealalta. Sitten pitää hakeutua opettajaksi opetuksen ohjausta antavaan oppilaitokseen. Vasta sen jälkeen pääsee teoreettisluonteiseen, kaksi lukukautta kestävään opettajankoulutukseen. Auskultantilta vaaditaan siis käytännön kokemusta sekä liikealalta että opetustyöstä.

\section{Tulevaisuuden opettaja}

Keskusteltaessa opettajan asemasta tulevaisuudessa todettiin, että "Viva vox docet" -periaate säilyy, eli koneet eivät tule syrjäyttämään ihmistä opettajana. Opettajan tärkeä työväline on hänen persoonallisuutensa. Se on tärkeämpi kuin tiedon runsaus tai opetusmenetelmät. Tärkeätä on, että opettaja itse 
uskoo opettamaansa asiaan ja sen tärkeyteen, sillä vain siten oppilaat voivat kokea sen tärkeäksi.

Perinteinen opettajan rooli on muuttumassa. Oppilaskeskeisessä opetuksessa opettaja on osallistuja, motivoija, neuvoja, joka antaa alkusysäyksen oppimiseen ja joka ohjaa oppilaitaan. Tietysti opettaja on edelleen organisoija ja opetuksen kehittäjä. Myös oppilaan pitäisi omaksua nämä roolit itselleen, jotta toteutuisi oppimisen lopullinen päämäärä: elinikäinen opiskelu.

Kokonaisvaltaisessa oppimistilanteessa pitäisi kehittää oppilaan viestintätaitoja, yhteistyökykyä, vastuuntuntoa ja osallistumisvalmiutta, sillä nämä ovat tärkeitä ominaisuuksia myös tulevaisuudessa.

Hyvä opettaja vaihtelee opetusmenetelmiään, kokeilee uusia opetustapoja. Näin hän kehittää omaa persoonallisuuttaan, ja samalla työ tulee vaihtelevaksi.

Ajatus Yhdentyvästä Euroopasta ohjaa kauppaopetuksen kehittämistä. Tutkintojen ja todistusten pitäisi vastata toisiaan eri maissa.

\section{Yhteistyö talouselämän ja kaup- paoppilaitosten välillä}

Tohtori Gerhard Heinrich Itävallan teollisuusliitosta (Vereinigung Österreichischer Industrieller) totesi, että talouselämän ja koulujärjestelmän yhteistyöllä on pitkät ja hyvät perinteet Itävallassa, erityisesti Salzburgin maakunnassa.

Konkreettisena osoituksena tästä yhteistyöstä on teollisuusliiton toivomuksesta koulutusta viime aikoina kehitetty seuraavasti:

- ensimmäisenn vuoden ohjelmaan on lisätty toinen vieras kieli

— opetuksessa pyritään laaja-alaisuuteen esim. ylittämällä oppiainerajoja

— sekä käytännönläheisyyteen, esimerkkinä tietokoneavusteinen laskentatoimi uutena aineena
— oikeinkirjoitukseen ja äidinkielen hallintaan kiinnitetään enemmän huomiota.

Yrityksiltä on tiedusteltu, mitä he odottavat vastavalmistuneilta. Liike-elämä Itävallassa painottaa seuraavia ominaisuuksia:

- perustiedot ja -taidot kustannuslaskennasta, hintalaskelmista ja viestinnästä

— perustiedot talouselämästä

— teknistä tietämystä sekä myönteistä suhtautumista teknologiaan

- henkilökohtaiset ominaisuudet: ennakointi, ongelmien tiedostaminen, analyyttinen ajattelu, halu oppia, kyky yhteistyöhön, mutta myös itsenäiseen työskentelyyn.

Nämä kaikki optimaaliset ominaisuudet voidaan tiivistää sanoen: "Kauppaopetuksen tulee antaa kaupalliset perustiedot sekä luoda hedelmällinen pohja elinikäiseen oppimiseen."

Tohtori Heinrich totesi terävästi elinikäisen oppimisen koskevan myös opettajia. Saksan liittotasavallassa viime vuonna tehty tutkimus osoittaa, että opiskelijoiden tiedot ja taidot ovat suoraan riippuvaisia heidän opettajiensa tasosta.

Tämä merkitsee suuria haasteita opettajien koulutukselle, varsinkin jatkokoulutukselle, jossa elävä yhteys liike-elämään on välttämätöntä.

Järjestetty opettajien työharjoittelu ottaa niin Itävallassa kuin Suomessakin ensiaskeliaan.

\section{Keskeiset keskuteluaiheet}

Aktiivisimman osan konferenssissa muodostivat työryhmät, joissa käsiteltiin mm. opetusmenetelmiä, tietotekniikan opetusta ja aikuiskoulutusta.
Keskeisiä keskusteluaiheita olivat $\mathrm{mm}$.

- Koulutus- ja kustannusvastuu

— Opetussisällöt

- Jatkuvan koulutuksen periaate

- Aikuisopiskelijan taloudellinen asema

- Euroopan yhdentymisen haasteet aikuiskoulutukselle

Joitakin huomioita keskustelun pohjalta:

Omaehtoisen ammatillisen aikuiskoulutuksen (vapaa-aikana, itse maksettu) suosio Keski-Euroopassa on huomattavasti suurempi kuin Suomessa. Onko syynä sikäläisen ammattiyhdistysliikkeen kannanotto ja suositukset omaehtoiseen koulutukseen?

Keskeisiä ongelmia Yhdysvaltain aikuiskouluttajilla ovat koulutettavien luku- ja kirjoitustaidottomuus. Tarvitsevatko ja haluavatko kaikki koulutusta?

Koulutustarpeen määrittely eli onko kyseessä työnantajan vai yksilön koulutustarve.

Mikä on koulutuksen merkitys yksilön kannalta?

Suomen mallia aikuiskoulutusosastojen perustamisesta ammatillisiin oppilaitoksiin pidettiin kustannuksiltaan edullisena ja joustavana järjestelynä. Koituuko liiallinen kustannusten säästö esteeksi osastojen kehittämiselle?

Aikuiskoulutuksen muun koulutuksen ohella - tulee vastata Euroopan yhdentymisen mukanaan tuomiin haasteisiin: työvoiman liikkuvuus, koulutuksen vastaavuus, jne. Vuosi 1992 on lähempänä kuin voimme kuvitella...

SIECin toiminnan tarkoituksena on edistää kaupallisen alan ammatillista koulutusta sekä elinkeinoelämän ja koulutusorganisaatioiden yhteistyötä. Järjestön julkaisu, SIEC Review, ilmestyy 2-3 kertaa vuodessa, osin kolmella kielellä: englanti, ranska, saksa. Suomen osasto on nimeltään Kaupallisen kasvatuksen edistämisyhdistys. 